\title{
Analysing the Lexical Demands of Subject Textbooks Used in Irish Post-Primary Education to Facilitate Immigrant Students' Curriculum Access
}

\author{
Stergiani Kostopoulou \\ University of Dublin, Trinity College \\ kostopos@tcd.ie
}

\begin{abstract}
This research uses a corpus-based methodology to analyse the lexical features of textbooks used in six curriculum subjects of Irish post-primary education (namely, English, History, Civic, Social and Political Education, Mathematics, and Science) to inform the English language support that is provided to immigrant students. The empirical analysis illuminates the commonest words, collocations and 4-word clusters in subject-specific registers, demonstrating the lexical variation that is manifested across subjects. From a pedagogical perspective, the discussion describes important features of students' target linguistic repertoire. Although the results are context-specific, the research methodology becomes relevant to any other context with similar pedagogical needs.
\end{abstract}

\section{Introduction}

The principal goal of English language support provided to immigrant students in Irish post-primary (secondary) education is to help them master the language of school subjects for curriculum access and integration into the mainstream classroom. Gaining control of the lexical resources required in the different content areas is fundamental to this end, considering the instrumental role that vocabulary (i.e. single words) and lexis (i.e. linguistic units that tend to co-occur) play in successful second language learning (e.g. Nattinger and DeCarrico 1992; Lewis 1993). The specialised vocabulary (and particularly lexical words) of school subjects has a gate-keeping function for students because it provides access to entire knowledge categories (Corson 1985). Collocations, i.e. 'combination[s] of two words [or, more precisely,

(cc) BY-NC-ND 
of word types] that exhibit a tendency to occur near each other in natural language' (Evert 2008: 1214), and word clusters, i.e. recurrent strings of two or more words that appear more frequently than expected by chance in a particular linguistic register, are equally important. Both are pervasive in natural language and they have been found to contribute to the fluency and naturalness of linguistic production by native and non-native speakers of a language (e.g. Pawley and Syder 1983; Howarth 1998; Hyland 2008). They further function as fundamental building blocks of academic discourse (Biber et al. 1999; Biber et al. 2004; Biber 2006) and shape context-specific meanings (Hyland 2008).

Despite their importance, however, it appears that subject-specific vocabulary and lexis, but also more broadly curriculum language, fail to receive their due attention in the language support class. Research into current practices (Lyons and Little 2009; Smyth et al. 2009) reveals that English language instruction is inappropriately or insufficiently linked to the specialized language demands of the post-primary curriculum, failing, as a result, to effectively address immigrant students' needs. This failure can be attributed to the lack of a clear understanding of the language students encounter in the subject classroom, as there has been no empirical research into this area.

To bridge this knowledge gap, the present research aims to provide an empirical description of the lexical features of six post-primary curriculum subjects - namely English, Geography, History, Civic, Social and Political Education (CSPE), Mathematics, and Science - as these are manifested in commonly-used textbooks of Junior Cycle education (i.e. the first three years of post-primary education). The methodology used to address this aim is described in the following section.

\section{Research Methodology}

To make curriculum language more visible, this research conducts a frequency analysis of six corpora that were designed to represent the language of commonly used textbooks used in six Irish post-primary curriculum subjects: English, Geography, History, CSPE, Mathematics and Science. Each subjectspecific corpus comprises the full contents of four widely used textbooks. The 24 textbooks were scanned and converted into electronic files which were edited (graphic and visual elements were removed) and stored as text files. As can be seen in Table 1 below, their size may not be very large, compared to the corpora of billion words that can be built today. It is, nevertheless, appropriate for the aims and purposes of this research as this examines specialised language registers rather than general English language (cf. for example O'Keeffe et al. 2007: 198; Bowker and Pearson 2002: 48). 
Table 1.

Composition of the six corpora built on Junior Cycle subject textbooks ${ }^{1}$

\begin{tabular}{|l|l|l|}
\hline Subject corpus & \# of textbooks & \# of tokens \\
\hline English & 4 & 451,784 \\
\hline Geography & 4 & 330,257 \\
\hline History & 4 & 367,708 \\
\hline CSPE & 4 & 213,340 \\
\hline Mathematics & 4 & 336,738 \\
\hline Science & 4 & 328,426 \\
\hline
\end{tabular}

The corpora in question are also multi-author, i.e. comprising textbooks written by different authors, in order to neutralise idiosyncratic language use by individual writers.

The frequency analysis of the six corpora focused on content words, significant collocations and 4-word clusters and it was facilitated by the Word List of WordSmith tools (Scott 2004). Frequency information can be used as an important criterion in prioritising what language should be taught the assumption being that, the more times students encounter a word, the more easily and faster they will understand it in their textbooks and might learn how to use it productively (see Milton 2009: 25-43 for a frequency model of vocabulary learning). To single out content words from the frequency wordlists computed by WordSmith, Nation's (2001: 430-431) function word list was used as a stop-list filter. Statistically significant collocations limited to occurrences within a five-word span were computed based on the loglikelihood ratio ( $\mathrm{G}^{2}$; Dunning 1993). This is a statistical measure of calculating the significance of word co-occurrence to filter out idiosyncratic collocations, i.e. frequently-used word pairs formed by chance.

For reasons of practical manageability, a relatively high cut-off point of frequency of occurrence was set (a minimum frequency of 40 times per million words) for the analysis of lexical features. In addition to minimal frequency requirements, range (i.e. consistency of use across texts in a corpus) was also used as a criterion for selecting the words and clusters to be closely examined, setting an occurrence in at least $75 \%$ of the texts that comprise a single corpus (i.e. in at least three out of four textbooks) as a minimum. This was essential to ensure that the idiosyncratic language use of individual textbook authors does not influence the results. Finally, abbreviations, numbers and symbols were excluded from the study. To facilitate a qualitative treatment of corpus data, numerical information

$\mathbf{1}$ The hash symbol (\#) refers to number. 
on frequency and range does not form part of this discussion. Due to space restrictions, the three types of high frequency lexical features in all six corpora are presented and discussed together in the next section.

\section{Presentation and Discussion of Findings}

From a close examination of the commonest content words, collocations and 4-word clusters in the six subject-specific corpora, displayed in Tables 2, 3 and 4, two major conclusions can be drawn. What can be immediately observed is the topic-specificity of the commonest lexical features in the six corpora. Regardless of the unit of analysis, i.e. word, collocation, 4-word cluster, the lexical choices of individual corpora seem to be largely influenced by the thematic content and communicative needs of the corresponding curriculum subjects.

Therefore, the commonest features in the English corpus mainly highlight the literary dimension of the subject (e.g. story, write, poem, words, read) and the emphasis that is placed on answering questions and justifying personal opinions (e.g. answer questions, give reasons, what do you think, etc.). In the Geography and History corpora, the most frequent words and collocations directly reflect the focus of study on people and the environment (e.g. countries, city, map, water, population density, acid rain) and on past issues, events, and historical figures (e.g. Irish, world war, De Valera, Fianna Fáil, international relations) respectively. The notion of time is also prominently featured by history-specific lexical words and collocations (e.g. time, middle ages, twentieth century). Clusters in the Geography corpus are mainly associated with references to visual aids (e.g. a sketch map of, the ordnance survey map, shown on the map) while clusters in the History corpus describe issues and time periods of historical significance (e.g. the War of Independence, agricultural and industrial revolutions, in the twentieth century, during the middle ages).

Table 2.

The 20 most frequent content words in the six textbooks-based corpora (cut-off frequency point - 40 per million words, range - $100 \%)$.

\begin{tabular}{|l|l|}
\hline English & $\begin{array}{l}\text { story, like, write, said, think, answer, poem, words, people, time, make, read, good, } \\
\text { give, see, writing, just, use, new, well }\end{array}$ \\
\hline Geography & $\begin{array}{l}\text { people, map, population, areas, water, area, countries, city, river, land, following, } \\
\text { figure, South, world, sea, large, photograph, new, high, explain }\end{array}$ \\
\hline History & $\begin{array}{l}\text { people, war, Irish, government, century, British, new, world, became, used, made, } \\
\text { called, year, land, army, great, church, time, following, work }\end{array}$ \\
\hline CSPE & $\begin{array}{l}\text { people, action, community, rights, local, world, work, school, government, project, } \\
\text { European, make, Irish, class, children, council, day, group, groups, think }\end{array}$ \\
\hline Mathematics & $\begin{array}{l}\text { find, centimetres, number, calculate, line, area, value, equation, point, example, } \\
\text { given, following, solution, angle, sides, length, graph, diagram, solve, sine }\end{array}$ \\
\hline Science & $\begin{array}{l}\text { water, energy, used, light, air, food, test, heat, experiment, called, plants, oxygen, } \\
\text { tube, gas, place, method, carbon, plant, acid, current }\end{array}$ \\
\hline
\end{tabular}


Table 3.

The top 20 most significant collocations in the six subject textbooks corpora ranked by descending order of significance based on $\mathrm{G}^{2}$ scores (frequency threshold $\mathrm{F} \geq 10$, minimum range $75 \%$ ).

\begin{tabular}{|l|l|}
\hline Textbooks corpus & Collocations \\
\hline English & $\begin{array}{l}\text { at the, do you, from the, what is, do think, your answer, what do, give reasons, } \\
\text { what you, will be, have been, answer questions, write a, out of, would be, look } \\
\text { at, had been, if you, going to, questions follow }\end{array}$ \\
\hline Geography & $\begin{array}{l}\text { such as, ordnance survey, per cent, have been, grid reference, more than, your } \\
\text { answer, can be, what is, case study, may be, inner city, has been, acid rain, } \\
\text { number of, they are, between and, these are, population density, sketch map }\end{array}$ \\
\hline History & $\begin{array}{l}\text { twentieth century, such as, set up, world war, De Valera, Northern Ireland, } \\
\text { during the, Home Rule, international relations, Fianna Fáil, more than, junior } \\
\text { history, middle ages, prime minister, did not, relations century, how did, } \\
\text { between and, political in, what was }\end{array}$ \\
\hline CSPE & $\begin{array}{l}\text { action project, human rights, United Nations, young people, find out, by the, } \\
\text { has been, set up, there are, European Union, number of, answer questions, will } \\
\text { be, do think, can be, right to, do you, more than, this is, asylum seekers }\end{array}$ \\
\hline Mathematics & $\begin{array}{l}\text { calculate the, value of, on the, how many, area of, both sides, write down, number } \\
\text { of, each following, calculate of, correct to, standard rate, surface area, image } \\
\text { under, under symmetry, at the, image of, Venn diagram, average speed, tax paid }\end{array}$ \\
\hline Science & $\begin{array}{l}\text { carbon dioxide, test tube, can be, Bunsen burner, experiment to, as shown, } \\
\text { such as, set up, higher level, this is, what is, apparatus used, number of, used to, } \\
\text { retort stand, living things, at the, result conclusion, centre gravity, through the }\end{array}$ \\
\hline
\end{tabular}

Several words and patterns that refer to people, individuals and organizations can be found in the CSPE corpus (e.g. children, young people, asylum seekers, government United Nations, European Union). The concept of rights, which is fundamental to the discourse of CSPE, also occurs among the top lexical features of CSPE textbooks (e.g. human rights, rights of the child, has the right to). As regards the commonest items in the corpora of the two more technical subjects of Mathematics and Science, these reveal major concepts and issues of mathematical and scientific study (e.g. number, value, equation, surface area and energy, current, carbon dioxide respectively). They further express instructions and tasks in which students engage in the classroom; these concern the practices of counting and measurement in mathematics (e.g. find the value/image/equation of, divide both sides by) and conducting experimental work in science (e.g. set up the apparatus, experiment to show that). Overall, the lexical variation that exists across the subject-specific corpora of Irish post-primary textbooks adds further evidence to the existing research evidence about the linguistic variation that exists across disciplines (e.g. Biber et al. 1999; Hyland 2008, etc.).

Another tendency that can be discerned based on the frequency results of the lexical analysis of the six subject-specific corpora is the recycling of the commonest features within the commonest word patterns. Examples of frequent content words and collocations which are embedded within some of the commonest 4-word clusters in the six corpora include the following:

English: think, give-reasons, answer-questions, do-think, questions-follow

Geography: map, grid-reference, ordnance-survey, sketch-map 


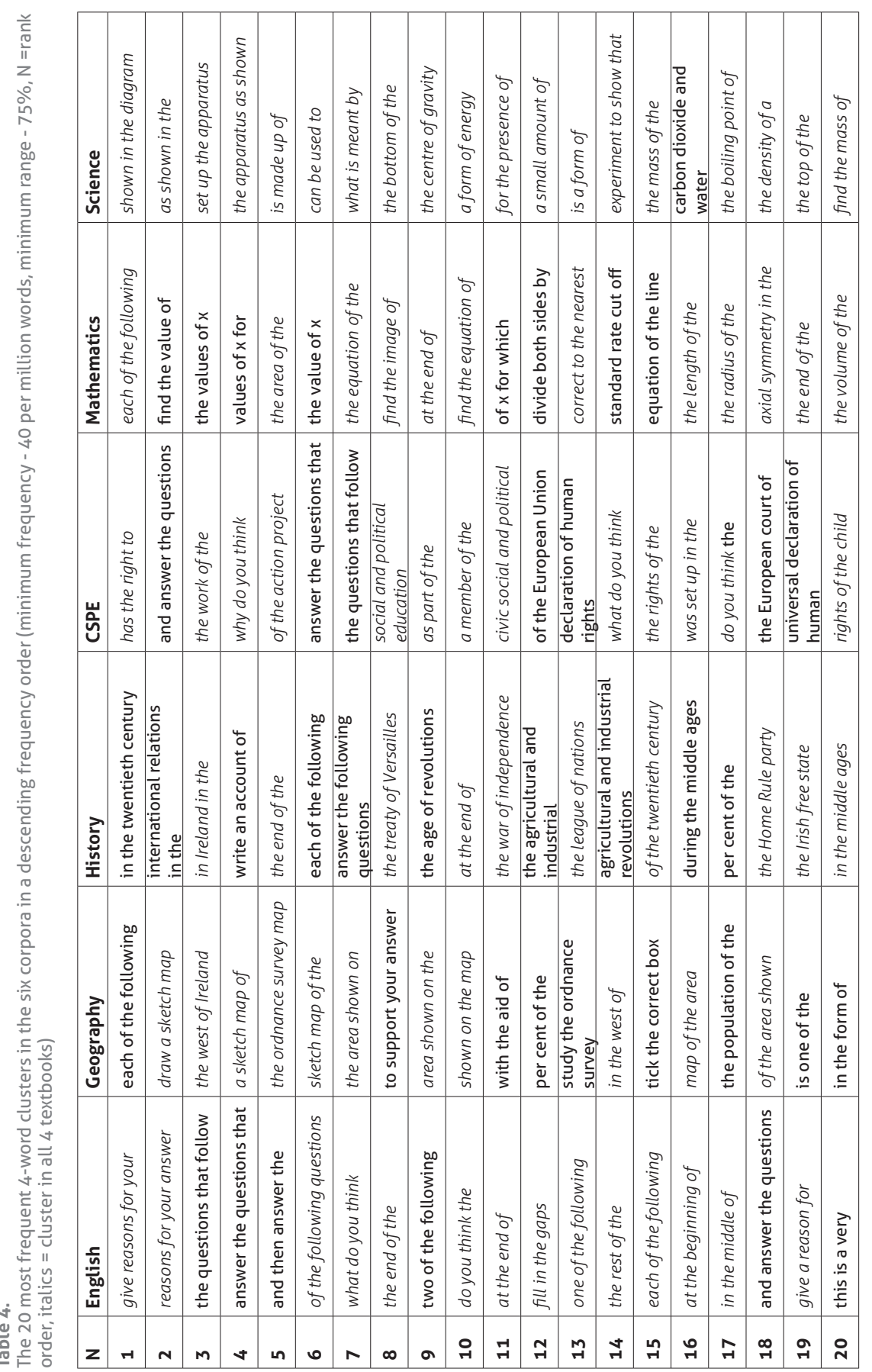


History: century, international-relations, twentieth-century, industrialrevolution, home-rule, middle-ages

CSPE: rights, action-project, European-Union, human-rights, universal-declaration Mathematics: value, standard-rate

Science: energy, carbon-dioxide, experiment-show, centre-gravity

Interestingly, even when these high-frequency words and collocations are not embedded within 4-word clusters, concordance lines show that they are manifested as their complementation items, i.e. the words that follow or precede them. The following are some illustrative examples from the six corpora (content words are underlined and enclosed in parentheses and collocations are simply enclosed in parentheses; intervening words are placed within square brackets):

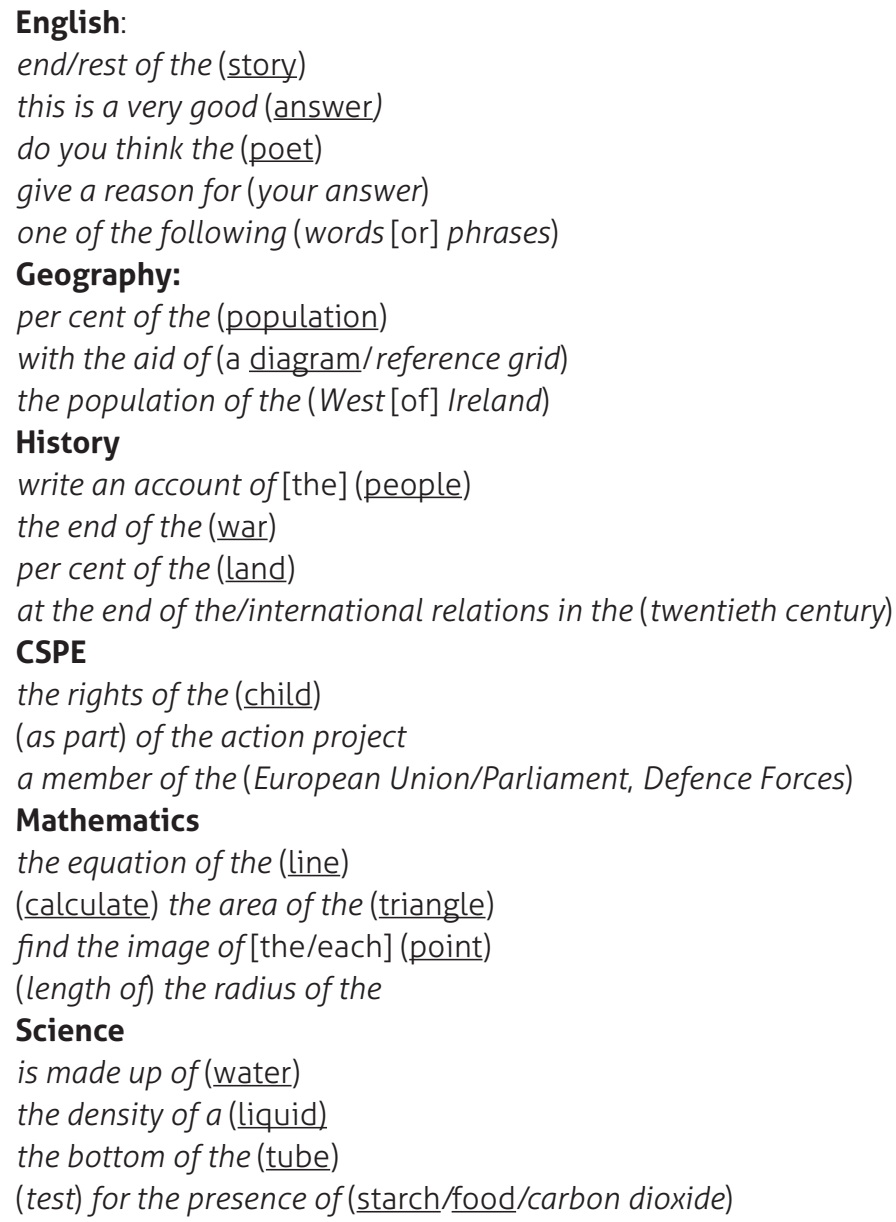


The above patterns attest to Sinclair's argument that: 'by far the majority of text is made of the occurrence of common words in common patterns or in slight variants of these patterns' (1991: 108). This observation about the lexical patterning of texts challenges the compositional view of language and supports the idiom principle according to which 'the language user has available to him a large number of preconstructed or semi-constructed phrases that constitute single choices, even though they appear to be analysable into segments' (ibid.: 110).

The two conclusions that emerge from the analysis of the six subjectspecific corpora carry direct pedagogical implications for the provision of English language support to immigrant students in Irish post-primary schools. The subject-specific nature of lexical features clearly demonstrates that curriculum language is not a single uniform register but a constellation of diverse language varieties that correspond to the different subjects. This conclusion calls for an English for Specific Purposes approach in the language support class and, more specifically, for language teaching and learning which are firmly embedded within the mainstream curriculum. Therefore, at a practical level, the descriptions of the lexical preferences of the six subjects provided here can be profitably used to facilitate thematically-based vocabulary teaching and learning and help teachers and students appreciate the lexical 'uniqueness' of subject-specific texts, that is, 'what makes [one subject-specific] text different from all other texts' (Nation 2001: 205).

The repeated use of high frequency lexical words in the most frequent collocations and the recycling of the commonest words and collocations within or adjacent to several highly frequent 4-word clusters highlight, on the one hand, the 'power' and 'utility' of the commonest words (Willis 1990) and the pre-patterned nature of subject-specific language, on the other. From a pedagogical perspective, this suggests that it is worthwhile teaching and learning the most frequent subject-specific words identified by this research due to their increased usefulness (the more often students encounter these words, the greater their need is to understand and use them). In addition, the lexical patterning that underpins subject-specific texts points to the need for a lexical approach (Lewis 1993) to language teaching and learning which takes lexis as its starting point viewing language as a phraseological system (Sinclair 1991). To this end, the repeated patterns of word cooccurrence described in the present discussion can be used to facilitate students' training in 'pedagogical chunking', that is 'breaking continuous text into useful component "bits"' (Lewis 1993: 120) within the meaningful communicative context of authentic subject-specific texts. 


\section{Conclusion}

This discussion described the commonest lexical words, collocations and 4-word clusters manifested in commonly used textbooks of six curriculum subjects of Irish Junior Cycle education. Although it was possible to present only a limited sample of findings ${ }^{2}$, the discussion has drawn two pedagogically useful conclusions about the nature of the lexical features that repeatedly occur in subject-specific texts. The first conclusion is that subject-specific texts value distinct sets of interrelated lexical words and phrases, and that these lexical preferences are highly determined by the information content of particular texts. The second conclusion is that subject-specific texts are underpinned by lexical patterning which is built upon the most frequent content words favoured by individual subjects.

Taken together, corpus-based data and descriptive insights into the nature of curriculum language can have multiple applications in the English language support classroom. The present empirical findings can, first of all, inform the content of a principled and explicit teaching agenda for language support teachers and facilitate decisions about the vocabulary component (selection, sequence, gradation, etc.). The corpus-based lexical inventories for the six subjects can also be directly exploited in the development of context-specific materials and language tests so that these can accurately reflect students' authentic language learning needs. In short, if learning, teaching and assessment are underpinned by the same corpus-based language specifications, then a coherent and effective language pedagogy can be promoted and multiple links can be established between English language support and the mainstream subject classroom.

Overall, this research addresses the lack of empirical information on the language of the Irish post-primary curriculum and the demands this imposes on immigrant students. At a more general level, the research responds to the calls for more applied corpus linguistics studies which are motivated by an interest in second language education specifically in the context of secondary education (e.g. Coxhead 2010: 466; Flowerdew 2009: 345). Moving beyond the Irish context, and considering that the linguistic integration of immigrant students is, and will remain, a common challenge for all educational systems, the design and methodology of this research has the potential to be adapted for use in other migrant education settings with similar pedagogical needs.

$\mathbf{2}$ See Kostopoulou 2012 for a detailed discussion of the language of Irish post-primary subject textbooks and examination papers. 


\section{References}

Biber, D. 2006. University language: a corpus-based study of spoken and written registers. Amsterdam; Philadelphia: John Benjamins.

Biber, D., Conrad, S. and Cortes, V. 2004. If you look at... : Lexical bundles in university teaching and textbooks. Applied Linguistics 25, 371-405.

Biber, D., Johansson, S., Leech, G., Conrad, S., and Finegan, E. 1999. Longman grammar of spoken and written English. London: Longman.

Bowker, L. and Pearson, J. 2002. Working with specialized language: A practical guide to using corpora. London: Routledge.

Corson, D. 1985. The lexical bar. Oxford: Pergamon.

Coxhead, A. 2010. What can corpora tell us about English for Academic Purposes?. In M. McCarthy and A. O'Keeffe (eds.), The Routledge handbook of corpus linguistics. London: Routledge, 458-470.

Dunning, T. 1993. Accurate methods for the statistics of surprise and coincidence. Computational Linguistics 19 (1), 61-74.

Flowerdew, L. 2009. Corpora in language teaching. In M. Long and C. Doughty (eds.), The handbook of language teaching. Oxford: Blackwell, 328-350.

Howarth, P. 1998. Phraseology and second language proficiency. Applied Linguistics 19 (1), 24-44.

Hyland, K. 2008. As can be seen: Lexical bundles and disciplinary variation. English for Specific Purposes 27(1), 4-21. 
Kostopoulou, S. 2012. Developing English language support for immigrant students in Irish post-primary schools: A corpus linguistics approach. (Unpublished PhD Thesis). Trinity College Dublin, Ireland.

Lewis, M. 1993. The lexical approach. Hove: Teacher Training Publications.

Lyons, Z. and Little, D. 2009. English language support in Irish post-primary schools: Policy, challenges and deficits. Dublin: Trinity Immigration Initiative, Trinity College Dublin.

Milton, J. 2009. Measuring second language vocabulary acquisition. Bristol: Multilingual Matters.

Nation, P. 2001. Learning vocabulary in another language. Cambridge: Cambridge University Press.

Nattinger, J. and DeCarrico, J. 1992. Lexical phrases and language teaching. Oxford: Oxford University Press.

O'Keeffe, A., McCarthy, M. and Carter, R. 2007. From corpus to classroom: Language use and language teaching. Cambridge: Cambridge University Press.

Pawley, A.K. and Syder, F.H. 1983. Two puzzles for linguistic theory: Nativelike selection and nativelike fluency. In J.C. Richards and R.W. Schmidt (eds.), Language and communication. London and New York: Longman, 191-226.

Scott, M. 2004. WordSmith Tools version 4. Oxford: Oxford University Press.

Smyth, E., Darmody, M., McGinnity, F. and Byrne, D. 2009. Adapting to diversity: Irish schools and newcomer students. Dublin: The Economic and Social Research Institute.

Willis, D. 1990. The lexical syllabus: A new approach to language teaching. London: HarperCollins.

\section{Junior Cycle subject textbooks}

Ashe, L. and McCarthy, K. 2008. New Geography Junior Certificate. Dublin: Educational Company.

Barrett, J. and Richardson, F. 2000. Impact!: Social, civic and political education for Junior Certificate (4th edition). Dublin: Gill and Macmillan. 
Cassidy, C. and Kingston, P. 2002. We are the world: Civil, social and political education. Dublin: Mentor.

Coleman, K. 2007. Shortcuts to success: Science experiments for Junior Certificate. Dublin: Gill and Macmillan.

Cullen, G. 2003. Discovering science. Dublin: Mentor.

Fay, F. 2008. Shortcuts to success: Maps and photographs Junior Certificate Geography (2nd edition). Dublin: Gill and Macmillan.

Halpin, M. 2005. Shortcuts to success: Maths - Junior Certificate Higher Level. Dublin: Gill and Macmillan.

Halpin, M. 2006. Shortcuts to success: Maths - Junior Certificate Ordinary Level. Dublin: Gill and Macmillan.

Harrison, C. and Wilson, M. 2001. Make a difference!: Civil, social and political education for Junior Certificate. Dublin: Folens.

Hayes, C. 2003. New complete Geography (3rd edition). Dublin: Gill and Macmillan.

Hayes, C. 2006. Shortcuts to success: History Junior Certificate. Dublin: Gill and Macmillan.

Humphrey, G. 2001. New Concise Maths 1 Ordinary Level. Dublin: Gill and Macmillan.

Humphrey, G. 2001. New Concise Maths 2 Higher Level. Dublin: Gill and Macmillan. Kelly, P. 2003. New Frontiers in first year English (Junior Certificate). Dublin: Folens. Kelly, P. 2004. New Frontiers in second and third year English. Dublin: Folens.

Kieran, M. 2004. Exam start: Higher level Junior Certificate English. Dublin: Gill and Macmillan.

Lucey, D. 2002. The past today: Complete Junior Certificate History. Dublin: Gill and Macmillan.

Mullally, S. 2007. Science revision for Junior Certificate (4th edition). Dublin: Gill and Macmillan. 
O'Dywer, P. 2002. The human planet: Geography for Junior Certificate. Dublin: Gill and Macmillan.

O'Leary, D. 2007. History revision for Junior Certificate (3rd edition). Dublin: Gill and Macmillan.

Quinn, R. 1998. Taking action: Civil, social and political education for Junior Certificate. Dublin: C.J. Fallon.

Quinn, R. and O'Leary, D. 2002. Junior Certificate History: Door to the past. Dublin: Folens.

Rocks, F. 2004. Exam start: Ordinary level Junior Certificate English. Dublin: Gill and Macmillan. 
Major Trends in Theoretical and Applied Linguistics 